\title{
ANALISIS KESALAHAN SISWA DALAM MENYELESAIKAN SOAL MATEMATIKA MATERI KUBUS DAN BALOK PADA SISWA KELAS VIII SMP
}

\author{
Cristine Magdalena \\ Universitas Katolik Santo Thomas, Medan; \\ cristinemagdalena4@gmail.com
}

\begin{abstract}
Abstrak. Penelitian ini bertujuan untuk mendeskripsikan jenis-jenis kesalahan siswa dan factor-faktor penyebab kesalahan siswa kelas VIII SMP Santo Petrus Medan dalam menyelesaikan soal-soal matematika materi kubus dan balok berdasarkan prosedur Newman.Metode penelitian ini adalah deskriptif kualitatif. Pengumpulan data dilakukan menggunakan metode tes tertulis dan wawancara. Subjek dalam penelitian ini yaitu siswa kelas VIII SMP Santo Petrus Medan yang berjumlah 34 siswa.Hasil penelitian menunjukkan persentase kesalahan yang dilakukan siswa dalam menyelesaikan soal matematika terkait materi kubus dan balok berdasarkan prosedur Newman adalah: (a) persentase kesalahan membaca yang dilakukan siswa sebesar 23\%, (b) persentase kesalahan memahami konsep sebesar 38\%, (c) persentase kesalahan transformasi sebesar $9 \%$, (d) persentase kesalahan keterampilan proses sebesar 92\%, (e) persentase kesalahan penulisan jawaban akhir sebesar $81 \%$. Persentase kesalahan total siswa sebesar . faktor-faktor penyebab kesalahan siswa adalah tidak lancar membaca soal serta kurangnya pengetahuan tentang simbol-simbol yang terdapat dalam soal-soal matematika,tidak memiliki kemampuan menuliskan hal yang diketahui dan ditanyakan dalam soal dengan benar,tidak menguasai materi kubus dan balok,asal-asalan mengerjakan soal,tidak menyukai pelajaran matematika,tidak pahan dengan metode penyelesaian yang digunakan dengan benar,tidak paham dengan rumus yang seharusnya digunakan, terburu-buru dalam mengerjakan proses penyelesaian.
\end{abstract}

Kata Kunci. Kesalahan, Newman, penyelesaian soal matematika.

Abstract. This study aims to describe the types of student errors and the factors that cause errors in grade VIII students of St. Peter's Middle School in solving the mathematical problems of cubes and blocks based on the Newman procedure. The method of this research is descriptive qualitative. Data collection was

Cartesius: Jurnal Pendidikan Matematika Vol. 3, No. 1

CProdi Pendidikan Matematika Universitas Katolik Santo Thomas 
carried out using the written test and interview methods. The subjects in this study were students of class VIII of St. Peter's Junior High School Medan, amounting to 34 students. The results showed the percentage of errors made by students in solving math problems related to cube and beam material based on Newman's procedure were: (a) the percentage of reading errors made by students by $23 \%$, (b) the percentage of errors understanding the concept by $38 \%$, (c) the percentage of transformation errors by $9 \%$, (d) the percentage of process skills errors by $92 \%,(e)$ the percentage of errors writing the final answer by $81 \%$. The percentage of students total errors of. the factors that cause students to mistake are not fluently reading questions and lack of knowledge about the symbols contained in mathematical problems, do not have the ability to write things that are known and asked about the problem correctly, do not master the material of cubes and blocks, carelessly do the problems, don't like math lessons, don't stick with the solution methods used correctly, don't understand the formulas that should be used, hurry in working on the completion process.

Keywords. Error, Newman, math problem solving.

\section{PENDAHULUAN}

Pendidikan merupakan usaha sadar dan terencana untuk mengembangkan potensi diri seseorang. Hal ini sesuai dengan UU No 20 tahun 2003, bahwa pendidikan adalah usaha sadar dan terencana untuk mewujudkan suasana belajar dan proses pembelajaran agar peserta didik aktif mengembangkan potensi dirinya untuk memiliki kekuatan spiritual keagamaan, pengendalian diri, kepribadian, kecerdasan, akhlak mulia, serta keterampilan yang diperlukan dirinya, masyarakat, bangsa dan negara.

Pendidikan terkait erat dengan pembelajaran. Dengan adanya pembelajaran, kualitas sumber daya manusia dapat ditingkatkan. Salah satu pembelajaran yang perlu mendapat perhatian khusus adalah pembelajaran matematika. Pembelajaran matematika merupakan proses dimana siswa secara aktif mengkonstruksi pengetahuan matematika. Pengetahuan matematika akan lebih baik jika siswa mampu mengkonstruksi melalui pengalaman yang telah mereka miliki sebelumnya (Bernard 15:2015). Tujuan pembelajaran matematika menurut Kemendikbud 2013 yaitu

Cartesius: Jurnal Pendidikan Matematika Vol. 3, No. 1

CProdi Pendidikan Matematika Universitas Katolik Santo Thomas 
1. Membentuk kemampuan siswa dalam menyelesaikan suatu masalah secara sistematik.

2. Meningkatkan kemampuan intelektual, khususnya kemampuan tingkat tinggi siswa.

3. Melatih siswa dalam mengkomunikasikan ide-ide, khususnya dalam menulis karya ilmiah.

4. Mengembangkan karakter.

5. Memperoleh hasil belajar yang tinggi

Pada kenyataannya, hasil belajar matematika siswa belum sesuai dengan yang diharapkan. Hal ini ditunjukkan dengan rendahnya nilai formatif bulanan sebagai berikut:

Tabel 1. Nilai Formatif Siswa Kelas VIII Tahun 2018/2019

\begin{tabular}{cccccc}
\hline No. & Kelas & $\begin{array}{c}\text { Jumlah } \\
\text { Siswa }\end{array}$ & $\begin{array}{c}\text { Nilai Rata- } \\
\text { Rata }\end{array}$ & $\begin{array}{c}\text { Pencapaian KKM } \\
\mathbf{( \% )}\end{array}$ & KKM \\
\cline { 1 - 4 } 1. & VIII-I & 33 & 70,0 & $38 \%$ & \multirow{2}{*}{76} \\
\cline { 1 - 5 } 2. & VIII-II & 31 & 65,0 & $28 \%$ & \\
\cline { 1 - 4 } 3. & VIII-III & 32 & 67,9 & $56 \%$ & \\
\cline { 1 - 4 } 4. & VIII-IV & 33 & 72,5 & $76 \%$ & \\
\hline
\end{tabular}

Sumber: SMP Swasta Katolik Santo Petrus Medan

Rendahnya hasil belajar siswa juga diketahui pada kelas VIII-1 di SMP Santo Petrus Medan yang dilaksanakan pada 12 Febuari 2019. Hasil observasi menyatakan bahwa proses pembelajaran tidak semua siswa yang aktif dalam pembelajaran. Saat guru menjelaskan materi dan contoh soal, guru memberikan kesempatan kepada siswa untuk menyelesaikan soal, namun tidak ada siswa yang mampu menjawab. Selain itu, kesalahan yang sering muncul dalam menyelesaikan soal yaitu dibagian perhitungan pada lembar jawaban siswa.Setelah melakukan observasi, dilakukan wawancara terhadap salah satu guru mata pelajaran matematika yaitu ibu F. B. Malau. Ibu tersebut mengatakan ketika siswa diberikan soal pekerjaan rumah (PR), siswa masih belum mampu untuk menyelesaikannya dan pembelajaran masih bersifat teacher centered (berpusat pada guru).

Cartesius: Jurnal Pendidikan Matematika Vol. 3, No. 1

CProdi Pendidikan Matematika Universitas Katolik Santo Thomas 
Hasil minitest yang diperoleh dari siswa juga menunjukkan bahwa masih banyak terdapat kesalahan siswa dalam menyelesaikan soal minitest pada materi lingkaran. Berikut adalah soal yang diberikan pada saat minitest

1. Selembar seng berbentuk persegipanjang berukuran $50 \mathrm{~cm} \times 40 \mathrm{~cm}$. Seng itu dibuat tutup kaleng berbentuk lingkaran dengan jari-jari $20 \mathrm{~cm}$. Berapa luas seng yang tidak digunakan?

Dari soal nomor satu tersebut, salah satu siswa menjawab seperti yang disajikan pada gambar 1 dibawah ini:

\section{Jawaban}

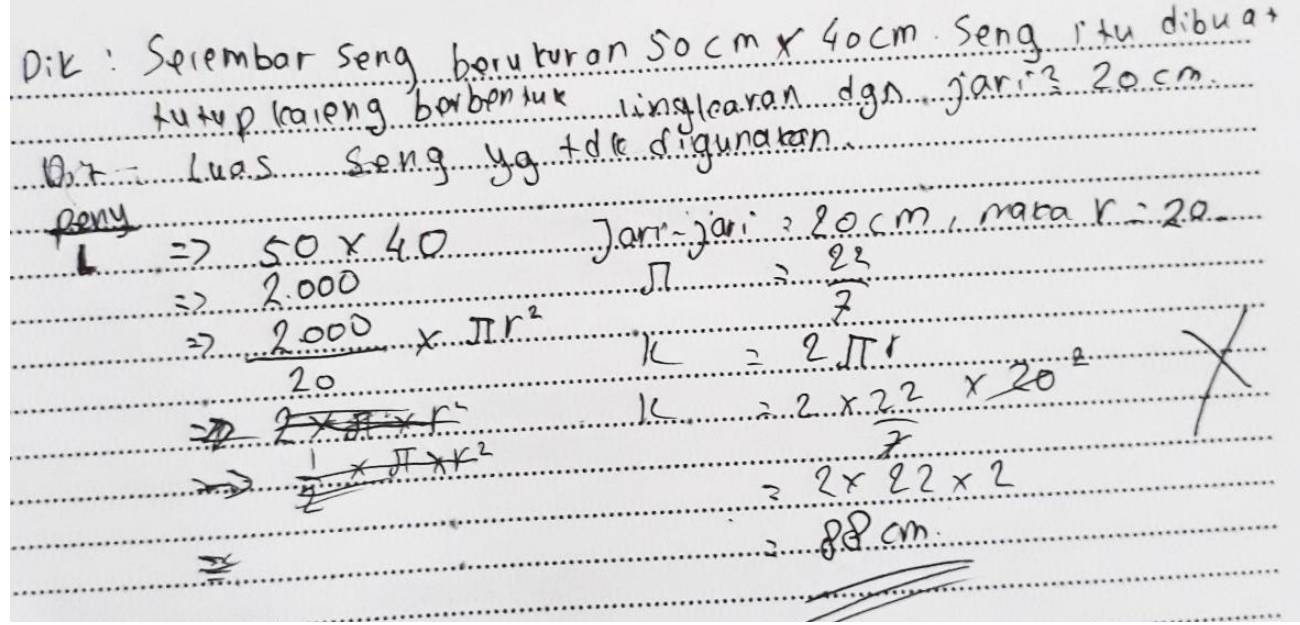

Gambar 1. Jawaban Siswa A Dalam Menyelesaikan Soal Nomor 1 Pada Saat Minitest

Pada gambar 1 di atas terlihat bahwa siswa A sudah menuliskan apa yang diketahui dan ditanyakan, artinya siswa A sudah bisa memahami soal. Akan tetapi siswa A tersebut salah menggunakan rumus. Pada hasil perhitungan yang dilakukan, terjadi kesalahan pada hasilnya. Siswa A menuliskan rumus $2 \pi r$ dan $1 \pi=\frac{22}{7}$ seharusnya rumus yang sebenarnya adalah $\pi r^{2}$ dan $\pi=3,14$, kemudian siswa A tidak menyelesaikan luas seng yang tidak digunakan. Ada 6 siswa (20\%) yang menjawab dengan benar dan 24 siswa (80\%) menjawab dengan salah. Sedangkan pada soal 2 yang diberikan pada saat minitest adalah sebagai berikut:

Cartesius: Jurnal Pendidikan Matematika Vol. 3, No. 1

CProdi Pendidikan Matematika Universitas Katolik Santo Thomas 
2. Dihalaman rumah pak Andi terdapat kolam hias. Kolam tersebut berbentuk lingkaran yang berdiameter 4,8 meter. Berapa luas tanah yang digunakan untuk membuat kolam tersebut?

Dari soal nomor 2 tersebut, salah satu siswa menjawab seperti yang disajikan pada gambar 2 di bawah ini:

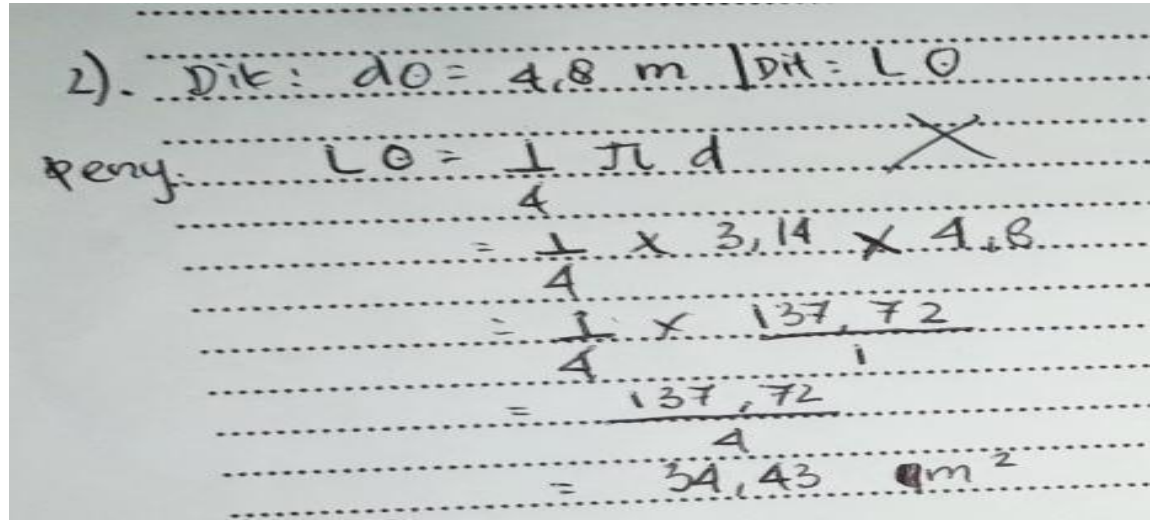

Gambar 2. Jawaban Siswa B Dalam Menyelesaikan Soal Nomor 2 Pada Saat Minitest

Pada gambar 2 di atas terlihat bahwa siswa B sudah menuliskan apa yang diketahui dan ditanyakan, artinya siswa B sudah bisa memahami soal. Akan tetapi siswa B tersebut salah menggunakan rumus. Pada hasil perhitungan yang dilakukan, terjadi kesalahan pada hasilnya. Terlebih dahulu siswa B tidak mencari jari-jari lingkaran.dan siswa B menuliskan rumus luas tanah $\frac{1}{4} \pi d$ yang seharusnya $\pi r^{2}$. Ada 2 siswa $(6,6 \%)$ menjawab dengan benar dan 28 siswa $(93,3 \%)$ menjawab dengan salah. Untuk soal nomor 3 yang diberikan pada saat minitest adalah sebagai berikut:

3. Sebuah lapangan berbentuk lingkaran memiliki keliling $88 \mathrm{~m}$. Tentukanlah luas lapangan tersebut: 


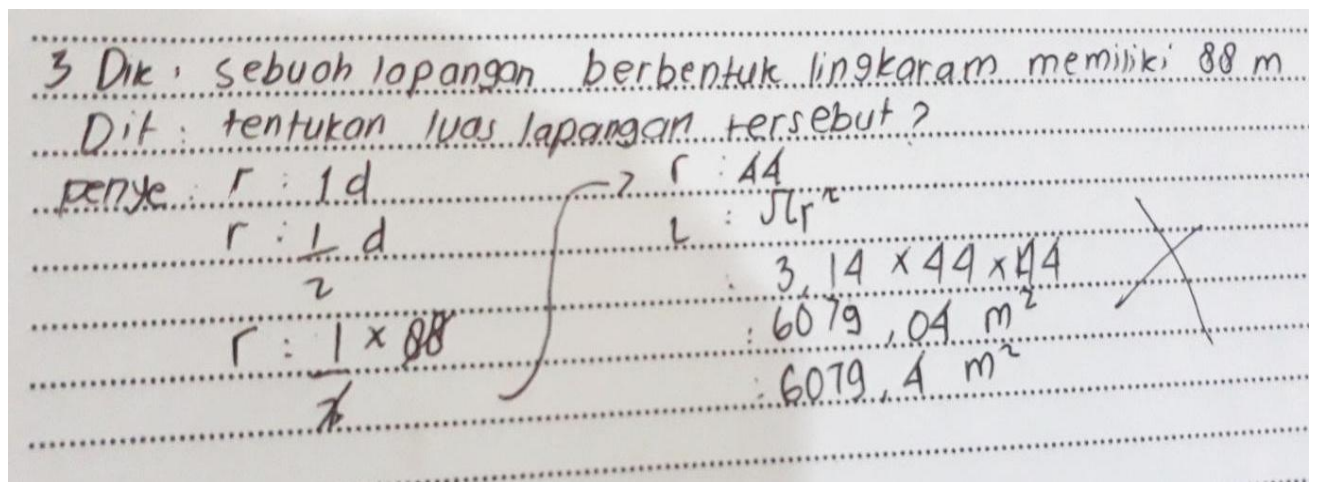

Gambar 3. Jawaban Siswa C Dalam Menyelesaikan Soal Nomor 3 Pada Saat Minitest

Pada gambar 3 di atas terlihat bahwa siswa $C$ sudah menuliskan apa yang diketahui dan ditanyakan, artinya siswa C sudah bisa memahami soal. Akan tetapi siswa $C$ tersebut salah menggunakan rumus. Pada hasil perhitungan yang dilakukan, terjadi kesalahan pada hasilnya. Siswa C menuliskan diameternya adalah 88, yang seharusnya itu merupakan keliling lingkaran bukan merupakan diameternya. Tidak ada satupun siswa $C$ yang menjawab soal dengan benar.

Untuk soal nomor 4 yang di berikan pada saat minitest adalah sebagai berikut:

4. Dua buah lingkaran memilik panjang garis singgung persekutuan luar 24 cm dan jarak kedua titik pusat lingkaran $26 \mathrm{~cm}$. Jika panjang jari-jari lingkaran besar $18 \mathrm{~cm}$, maka panjang jari-jari lingkaran yang lain adalah....

Dari soal nomor 4 tersebut, salah satu siswa menjawab seperti yang disajikan pada gambar dibawah ini

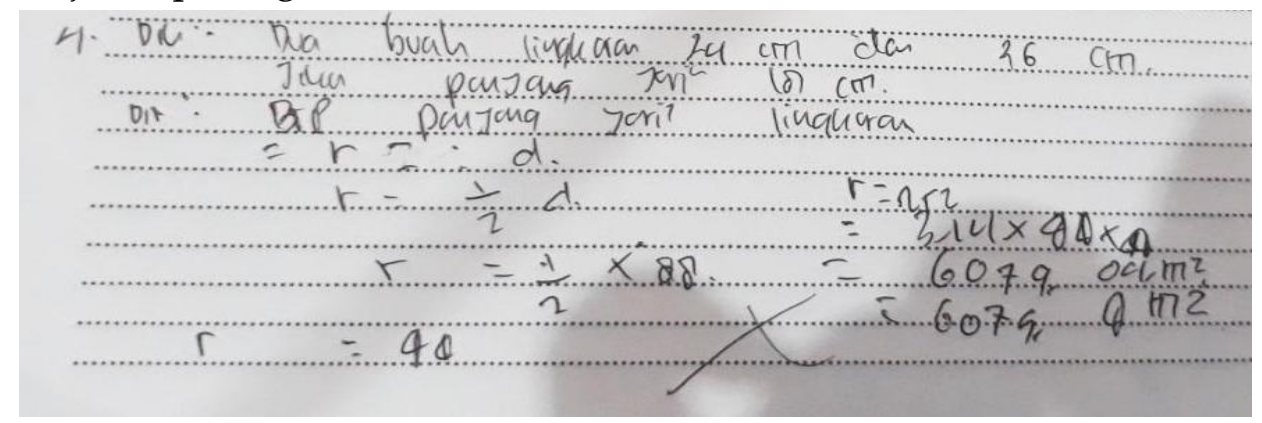

Gambar 4. Jawaban Siswa D Dalam Menyelesaikan Soal Nomor 4 Pada Saat Minitest

Cartesius: Jurnal Pendidikan Matematika Vol. 3, No. 1

CProdi Pendidikan Matematika Universitas Katolik Santo Thomas 
Pada gambar 4 di atas terlihat bahwa siswa D sudah menuliskan apa yang diketahui dan ditanyakan, artinya siswa D sudah bisa memahami soal. Akan tetapi siswa D tersebut salah menggunakan rumus. Pada hasil perhitungan yang dilakukan, terjadi kesalahan pada hasilnya. Siswa D menuliskan rumusnya $\frac{1}{2} d$ dan $\pi r^{2}$ yang seharusnya $r=R-\sqrt{p^{2}-G S P^{2}}$. Ada 1 siswa $(3,3 \%)$ yang menjawab dengan benar dan ada 34 siswa $(96,6 \%)$ yang menjawab dengan salah.

Kesalahan yang dilakukan siswa dalam menyelesaikan soal pemecahan masalah matematika materi peluang berdasarkan langkah Polya dihasilkan dalam proses memahami masalah sebesar $100 \%$, menyusun rencana $81 \%$, melaksanakan rencana $81 \%$ dan memeriksa kembali solusi sebesar $100 \%$. Kesalahan yang paling sering dilakukan siswa dalam mengerjakan soal pemecahan masalah matematika materi peluang yaitu kesalahan dalam menentukan apa yang diketahui dan ditanyakan, kesalahan dalam melaksanakan rencana, kesalahan dalam menentukan kesimpulan dan kesalahan dalam memeriksa kembali solusi. Kegiatan scaffolding yang dilakukan antara lain environmental provisions 25\%, explaining 25\%, restructing $17 \%$, reviewing $17 \%$, developing conceptual thinking $16 \%$. Kegiatan ini dapat meningkatkan kemampuan pemecahan masalah siswa pada materi peluang. Hal ini diketahui dari hasil tes siswa yang menunjukkan peningkatan serta respon positif siswa.

Berdasarkan uraian yang telah dijelaskan sebelumnya, maka perlu dilakukan penelitian terkait dengan Analisis Kesalahan Siswa Dalam Menyelesaikan Soal Matematika Pada Materi Kubus dan Balok di SMP St.Petrus Medan.

\section{METODE}

Penelitian ini menggunakan pendekatan kualitatif. Menurut Moleong (2011:6) penelitian kualitatif adalah suatu penelitian yang bertujuan untuk memahami hal-hal yang dialami oleh subjek penelitian, secara hilostik dan deskriptif dalam bentuk kata-kata dan bahasa, pada suatu konteks khusus yang alamiah dan dengan memanfaatkan berbagai metode ilmiah.

Cartesius: Jurnal Pendidikan Matematika Vol. 3, No. 1

CProdi Pendidikan Matematika Universitas Katolik Santo Thomas 
Pendekatan kualitatif dipilih dalam penelitian ini dengan tujuan agar dapat mengungkap secara lebih cermat kesalahan peserta didik dalam menyelesaikan soal kontekstual. Selain itu, dengan pendekatan kualitatif peneliti dapat berkomunikasi secara langsung dengan responden untuk mengetahui hal-hal yang berhubungan dengan kesalahan peserta didik dalam menyelesaikan soal kontekstual.

Subjek penelitian ini adalah siswa kelas VIII-I SMP Swasta Katolik Santo Petrus Medan dengan jumlah siswa 34 orang yang terdiri dari 15 perempuan dan 19 laki-laki.

Tehnik pengumpulan datayang digunakan sebagai berikut. Tes merupakan alat prosedur yang digunakan untuk mengetahui atau mengukur sesuatu dalam suasana, dengan cara dan aturan-aturan yang sudah ditentukan (Arikunto 2013:67). Tes dalam penelitian ini memuat soal uraian tentang materi kubus dan balok. Bentuk soal uraian dipilih untuk mengumpulkan data mengenai kesalahan siswa karena dalam menjawab soal uraian, siswa dituntut untuk menguraikan langkah-langkah ataupun proses yang dilakukan untuk menyelesaikan soal tersebut. Dari hasil pekerjaan siswa dapat terlihat jelas kesalahan-kesalahan yang mungkin dilakukan oleh siswa dalam mengerjakan soal. Wawancara Dalam penelitian ini, salah satu metode pengumpulan data yang dilakukan adalah wawancara untuk mengetahui hal-hal dari responden yang lebih mendalam. Wawancara dilakukan dengan tujuan untuk mengetahui dan mengungkap secara langsung seluruh informasi dari subjek penelitian.

\section{HASIL DAN PEMBAHASAN}

Hasil tes pada siswa diberikan 5 soal uraian, pada setiap soal terdapat indikator analisis kesalahan.

Cartesius: Jurnal Pendidikan Matematika Vol. 3, No. 1

CProdi Pendidikan Matematika Universitas Katolik Santo Thomas 
Tabel 2. Jumlah Kesalahan Yang Dilakukan Siswa

Pada Setiap Jenis Kesalahan

\begin{tabular}{cccccc}
\hline \multirow{2}{*}{\begin{tabular}{c} 
Nomor \\
\cline { 2 - 6 }
\end{tabular}} & $\begin{array}{c}\text { Reading } \\
\text { errors }\end{array}$ & $\begin{array}{c}\text { Comprehens } \\
\text { ion errors }\end{array}$ & $\begin{array}{c}\text { Transformatio } \\
\text { n errors }\end{array}$ & $\begin{array}{c}\text { Proces } \\
\mathbf{s} \\
\text { errors }\end{array}$ & $\begin{array}{c}\text { Encodin } \\
\text { g errors }\end{array}$ \\
\hline 1 & 15 siswa & 22 siswa & 30 siswa & $\begin{array}{c}30 \\
\text { siswa }\end{array}$ & 30 siswa \\
\hline 2 & 4 siswa & 4 siswa & 30 siswa & $\begin{array}{c}30 \\
\text { siswa }\end{array}$ & 30 siswa \\
\hline 3 & 5 siswa & 5 siswa & 30 siswa & $\begin{array}{c}30 \\
\text { siswa }\end{array}$ & 27 siswa \\
\hline 5 & 6 siswa & 6 siswa & 18 siswa & $\begin{array}{c}18 \\
\text { siswa }\end{array}$ & 21 siswa \\
\hline 5 & 5 siswa & 21 siswa & 27 siswa & $\begin{array}{c}30 \\
\text { siswa }\end{array}$ & 27 siswa \\
\hline Jumlah & $\mathbf{3 5}$ siswa & $\mathbf{5 8}$ siswa & $\mathbf{1 3 5}$ siswa & $\begin{array}{c}\mathbf{1 3 8} \\
\text { siswa }\end{array}$ & $\begin{array}{c}\mathbf{1 2 2} \\
\text { siswa }\end{array}$ \\
\hline Persentase & $\mathbf{2 0 \%}$ & $\mathbf{3 4 \%}$ & $\mathbf{7 9 \%}$ & $\mathbf{8 1 \%}$ & $\mathbf{7 1 \%}$ \\
\hline
\end{tabular}

Berdasarkan deskripsi hasil tes dan wawancara yang dilakukan pada siswa, maka dapat diketahui kesalahan-kesalahan yang dilakukan oleh siswa dalam menyelesaikan soal-soal materi kubus dan balok. Hasil analisis data yang diperoleh menunjukkan jenis-jenis kesalahan menurut metode Newmann dan persentase tingkat keslaahan pada setiap jenis kesalahan. Melalui hasil analisis data diketahui pula penyebab dari kesalahan yang dilakukan oleh siswa. Berikut pembahasan hasil analisis data yang diperoleh:

\section{a. Kesalahan Membaca (Reading Errors)}

Kesalahan membaca yaitu kesalahan yang dilakukan peserta didik pada saat membaca soal. Kesalahan membaca terjadi ketika peserta didik tidak mampu membaca kata-kata maupun simbol yang terdapat pada soal. Kesalahan yang dilakukan siswa pada aspek ini antara lain, siswa salah membaca kepanjangan dari simbol $\mathrm{p}, \mathrm{l}, \mathrm{t}, \mathrm{dm}$, dan $\mathrm{cm}$.

Cartesius: Jurnal Pendidikan Matematika Vol. 3, No. 1

CProdi Pendidikan Matematika Universitas Katolik Santo Thomas 
Tingkat kesalahan yang dilakukan siswa pada jenis kesalahan membaca (reading errors) yang diperoleh dari hasil perhitungan persentase tingkat kesalahan adalah sebesar $20 \%$.

\section{b. Kesalahan Memahami (Comprehension Errors)}

Kesalahan memahami masalah adalah kesalahan yang dilakukan peserta didik setelah peserta didik mampu membaca permasalahan yang ada dalam soal namun tidak mengetahui permasalahan yang ada dalam soal namun tidak mengetahui permasalahan apa yang harus ia selesaikan. Kesalahan yang dilakukan siswa pada jenis ini terlihat dari siswa yang tidak menuliskan hal yang diketahui dan hal yang ditanyakan oleh soal atau hanya menuliskan salah satunya saja pada lembar jawaban. Selain itu sebagian besar siswa ada yang menuliskan hal yang diketahui dan yang ditanyakan oleh soal, namun salah dalam menangkap informasi yang terdapat dalam soal sehingga siswa tidak dapat menyelesaikan permasalahan dengan benar dan tepat.

Tingkat kesukaran yang dilakukan siswa pada jenis kesalahan memahami (comprehension) yang diperoleh dari hasil perhitungan persentase tingkat kesalahan adalah sebesar $34 \%$.

\section{c. Kesalahan Transformasi (Transformation Errors)}

Kesalahan transformasi merupakan sebuah kesalahan yang terjadi ketika peserta didik telah benar memahami pertanyaan dari soal yang diberikan, tetapi gagal untuk memilih operasi matematika yang tepat untuk menyelesaikan permasalahan tersebut. Kesalahan jenis ini yang dilakukan oleh siswa terlihat dari siswa yang tidak mampu memilih rumus, ataupun salah dalam menggunakan rumus untuk menyelesaikan permasalahan dalam soal. Misalnya, siswa menggunakan rumus volume balok untuk mencari luas permukaan balok. Selain itu, sebagian besar siswa sudah benar dalam menentukan rumus awal yang digunakan, namun tidak menuliskan rumus selanjutnya untuk menyelesaikan permasalahan hingga tuntas. Atau dengan kata lain, siswa tidak mampu menentukan langkah-langkah penyelesaian dengan mengombinasikan rumus-rumus yang seharusnya

Cartesius: Jurnal Pendidikan Matematika Vol. 3, No. 1

CProdi Pendidikan Matematika Universitas Katolik Santo Thomas 
digunakan untuk menyelesaikan permasalahan dalam soal. Tingkat keslahan yang dilakukan siswa pada jenis kesalahan transformasi (Transformation errors) yang diperoleh dari hasil perhitungan persentase tingkat kesalahan adalah sebesar $79 \%$.

\section{d. Kesalahan Kemampuan Proses (Process Skill)}

Kesalahan kemampuan memproses adalah suatu kesalahan yang dilakukan peserta didik dalam proses perhitungan. Peserta didik mampu memilih pendekatan yang harus ia lakukan untuk menyelesaikan soal, tapi ia tidak mampu menghitungnya. Terdapat beberapa kesalahan yang dilakukan berkaitan dengan jenis kesalahan ini,terlepas dari kesalahan siswa sebelumnya (kesalahan transformasi), misalnya siswa tidak mampu mengoperasikan perkalian dan penjumlahan dengan benar.

Tingkat kesalahan yang dilakukan siswa pada jenis kesalahan kemampuan proses (process skill) yang diperoleh dari hasil perhitungan persentase tingkat kesalahan adalah sebesar $81 \%$.

\section{e. Kesalahan Penulisan (Encoding)}

Kesalahan penulisan merupakan kesalahan dalam proses penyelesaian yang menyebabkan siswa salah dalam atau tidak menentukan jawaban akhir dan tidak menuliskan kesimpulan. Kesalahan ini terjadi disebabkan oleh kesalahan-kesalahan sebelumnya yang dilakukan oleh siswa.

Tingkat kesalahan yang dilakukan siswa pada jenis kesalahan kemampuan proses (process skill) yang diperoleh dari hasil perhitungan persentase tingkat kesalahan adalah sebesar $71 \%$.

Berdasarkan hasil perhitungan persentase tiap jenis kesalahan didapatkan bahwa kesalahan terbesar yang dilakukan siswa yaitu pada jenis kesalahan kemampuan proses (Process Skill) sedangkan kesalahan terkecil yang dilakukan siswa pada jenis kesalahan membaca (reading errors).

Cartesius: Jurnal Pendidikan Matematika Vol. 3, No. 1

CProdi Pendidikan Matematika Universitas Katolik Santo Thomas 


\section{KESIMPULAN}

Berdasarkan hasil dan pembahasan, maka dapat diambil kesimpulan sebagai berikut:

1. Jenis kesalahan yang dilakukan siswa kelas VIII SMP Swasta Santo Petrus Medan dalam menyelesaikan soal materi bangun ruang berdasarkan analisis kesalahan Newmann terdiri dari 5 kesalahan, yaitu kesalahan membaca (reading errors), kesalahan memahami masalah (comprehension errors), kesalahan transformasi (transformation errors), kesalahan keterampilan proses (process skill), dan kesalahan penulisan (encoding errors).Kesalahan terbesar yang dilakukan siswa yaitu pada jenis kesalahan kemampuan proses (Process Skill) sebanyak 92\% sedangkan kesalahan terkecil yang dilakukan siswa pada jenis kesalahan transformasi (Transformation Errors) sebanyak 9\%.

2. Hasil perhitungan persentase kesalahan yang dilakukan siswa dalam menyelesaikan soal matematika terkait smateri kubus dan balok, yaitu persentase kesalahan membaca yang dilakukan siswa sebesar $23 \%$. Persentase untuk kesalahan memahami masalah sebesar 38\%. Persentase untuk kesalahan transformasi sebesar 9\%. Persentase untuk kesalahan keterampilan proses sebesar 92\%. Persentase untuk penulisan sebesar $81 \%$. Selain itu, persentase kesalahan total siswa adalah

3. Adapun faktor penyebab kesalahan yang dilakukan siswa dalam menyelesaikan soal materi kubus dan balok berdasarkan prosedur Newman diuraikan berikut ini:

a. Penyebab kesalahan membaca yaitu siswa kurangnnya pengetahuan siswa mengenai simbol-simbol yang biasa digunakan dalam soal matematika.

b. Penyebab kesalahan memahami yaitu siswa kesulitan menemukan hal yang diketahui dan hal yang ditanyakan dalam soal, siswa tidak mengerti dengan hal yang diketahui dan hal yang ditanyakan, siswa tidak teliti dalam menemukan hal diketahui pada soal, siswa lupa menuliskan hal yang diketahui dan ditanyakan dalam soal, dan siswa jarang membaca soal-soal terkait materi kubus dan balok.

c. Penyebab kesalahan transformasi diantaranya yaitu siswa tidak paham dengan metode penyelesaian yang digunakan, siswa bingung

Cartesius: Jurnal Pendidikan Matematika Vol. 3, No. 1

CProdi Pendidikan Matematika Universitas Katolik Santo Thomas 
harus menggunakan rumus yang tepat, siswa tidak tahu rumus yang seharusnya digunakan, siswa tidak focus untuk menyelesaikan soal, siswa tidak paham materi kubus dan balok, siswa kurang menyukai matematika, siswa jarang mengerjakan contoh-contoh soal terkait maeri kubus dan balok, dan siswa memiliki kemampuan kognitif yang rendah.

d. Penyebab kesalahan keterampilan proses diantaranya yaitu siswa tidak teliti dalam melakukan proses perhitungan dan siswa tidak paham dengan perhitungan yang digunakan

e. Penyebab kesalahan penulisan jawaban akhir yaitu akibat dari kesalahan sebelumnya dan tidak paham dengan hal yang ditanyakan dalam soal.

Merujuk dari hasil penelitian ini, maka peneliti mengemukakan beberapa saran sebagai berikut.

1. Untuk meningkatkan kemampuan membaca, khususnya soal pada materi matematika, sebaiknya siswa dibiasakan membaca contohcontoh soal matematika sehingga siswa tidak asing dengan simbolsimbol yang biasa dipakai dalam soal maematika

2. Untuk meningkatkan kemampuan penalaran dan berfikir siswa dalam memahami permasalahan pada soal materi matematika, sebaiknya siswa diberi pembelajaran dan latihan mengerjakan soal-soal yang lebih intensif, serta materi pembelajaran lebih dikaitkan dengan lingkungan sekitar maupun kehidupan sehari-hari sehingga siswa mudah menemukan hal yang diketahui dan hal yang ditanyakan dalam soal.

3. Untuk meningkatkan penguasaan rumus siswa, hendaknya siswa lebih ditekankan untuk tidak menghafalkannya melainkan untuk dipahami. Guru hendaknya memberikan konsep dasar rumus matematika sehingga siswa terbiasa dengan langkah prose penyelesaian soal dan tidak terpaku pada rumus yang mereka hafal

4. Untuk menghindari kesalahan yang dilakukan siswa, guru sebaiknya mengadakan bimbingan intensif bagi siswa-siswa yang mengalami

Cartesius: Jurnal Pendidikan Matematika Vol. 3, No. 1

CProdi Pendidikan Matematika Universitas Katolik Santo Thomas 
kesalahan dalam mengerjakan soal-soal matematika dan siswa yang memilik kemampuan kognitif rendah

\section{UCAPAN TERIMAKASIH}

Penulis menyampaikan terimakasih kepada Ibu Frida M. A. Simorangkir, S.Si., M.Pd. sebagai Dosen Pembimbing 1 dan Ibu Tetty Natalia Sipayung, S.Si., M.Pd. sebagai Dosen Pembimbing 2 yang telah mengarahkan dan membimbing penulis mulai dari awal penelitian hingga berakhirnya penelitian sehingga penulis dapat menuliskan artikel ini yang merupakan bagian dari hasil penelitian penulis. Penulis juga menyampaikan terimakasih kepada Kepala Program Studi Pendidikan Matematika, Dekan, dan Rektor Universitas Katolik Santo Thomas atas dukungan yang diberikan kepada penulis.

\section{DAFTAR PUSTAKA}

[1] Amalia \& Widyati. 2012. Analisis Butir Soal Tes Kendali Mutu Kelas XII SMA Mata Pelajaran Ekonomi Akuntasi di Kota Yogyakarta. Jurnal Pendidikan Akuntasi Indonesia. X(1).

[2] Amalia, Aufin \& Khusniah. 2018. Analisis Kesalahan dalam Menyelesaikan Soal Cerita Pada Pokok Bahasan Persamaan Linear Berdasarkan Newman Kelas X-MIA di SMA Bayt Al-Hikmah Kota Pasuruan. Jurnal Pendidikan Matematika.

[3] Arikunto, S. 2009. Prosedur Peneliian Suatu Pendekatan Praktek. Penerbit Rineka Cipta: Jakarta.

[4] Arnidha.2015. Analisis Kesalahan Siswa dalam Menyelesaikan Soal Operasi Hitung Bilangan Cacah. Jurnal E-dumath. I(I).

[5] Farida. 2015. Analisis Kesalahan Siswa SMP Kelas VIII dalam Menyelesaikan Masalah Soal Cerita Matematika. Jurnal Pendidikan Matematika. IV(2).

[6] Fatahillah.2017. Analisis Kesalahan Siswa salam Menyelesaikan Soal Cerita Matematika Berdasarkan Tahapan Newmann Beserta Bentuk Scaffolding yang Diberikan. Jurnal Pendidikan Matematika. VIII(1).

[7] Fitri, Helma \& Syarifuddin. 2014. Penerapan Strategi The Firing Line Pada Pembelajaran Matematika Siswa Kelas XI IPS SMA Negeri 1 Batipuh. Jurnal Pendidikan Matematika. III(1).

Cartesius: Jurnal Pendidikan Matematika Vol. 3, No. 1

CProdi Pendidikan Matematika Universitas Katolik Santo Thomas 
[8] Friedberg, Stephen H, Arnold J. Insel, Lawrence E, Spence. 1997. Linear Algebra Third Edition. Prentice-Hall International, Inc.

[9] Komarudin. 2016. Analisis Kesalahan Siswa dalam Pemecahan Masalah Matematika Pada Materi Peluang Berdasarkan High Order Thinking Dan Pemberian Scaffolding. Jurnal Pendidikan Matematika. VIII(1).

[10] Lestari, Rini Dwi. 2011. Analisis Kesalahan Siswa dalam Menyelesaikan Soal Faktorisasai Suku Aljabar Kelas VIII SMP Negeri 1 Jaten Tahun Ajaran 2010/2011.Skripsi. Surakarta: Studi S-1 FKIP Universitas Negeri Surakarta.

[11] Manibuy, Ronald, Mardiyana, dan Dewi Retno Sari Saputro. 2014. Analisis Kesalahan Siswa Dalam Menyelesaikan Soal Persamaan Kuadrat Berdasarkan Taksonomi Solo pada Kelas X SMA Negeri 1 Plus di Kabupaten Nabire - Papua. Jurnal Elektronik Pembelajaran Matematika. 2(9). Hal. 933945.

[12] Mulyadi, Riyadi, dan Sri Subanti. 2015. Analisis Kesalahan Dalam Menyelesaikan Soal Cerita Pada Materi Luas Permukaan Bangun Ruang Berdasarkan Newman's Error Analysis (NEA) Ditinjau Dari Kemampuan Spasial. Jurnal Elektronik Pembelajaran Matematika. 3(4). Hal. 370-382.

[13] Nurussafa'at, Fitri Andika, Imam Junadi, dan Riyadi. 2016. Analisis Kesalahan Siswa dalam Menyelesaikan Soal Cerita Pada Materi Volume Prisma Dengan Fong's Schematic Model for Error Analysis Ditinjau dari Gaya Kognitif Siswa Studi Kasus Siswa Kelas VII Semester II SMP IT Ibnu Abbas Klaten Tahun Ajaran 2013/2014. Jurnal Elektronik Pembelajaran Matematika 4(2). Hal. 174-187.

[14] Prakitipong, Natcha and Nakamura, Satoshi. 2006. Analysis of Mathematics Performance of Grade Five Studentsin Thailand Using Newman Procedure. CICE Hiroshima University, Journal of International Cooperation in Education. 9(1). Hal.111.

[15] Priyanto, Arif, Suharto, dan Dinawati Trapsilasiwi. 2015. Analisis Kesalahan Siswa dalam Menyelesaikan Soal Cerita Matematika Pokok Bahasan 14 Teorema Pythagoras Berdasarkan Kategori Kesalahan Newman di Kelas VIII A SMP Negeri 10 Jember. Jurnal Artikel Ilmiah Mahasiswa. 1(1). Hal.1-5.

[16] Rahmania \& Rahmawati. 2016. Analisis Kesalahan Siswa dalam Menyelesaikan Soal Cerita Persamaan Linear Satu Variabel. Jurnal Matematika Dan Pendidikan Matematika. I(2).

[17] Rindyana, Bunga Suci Bintari \& Chandra, Tjang Daniel. 2012. Analisis Kesalahan Siswa dalam Menyelesaikan Soal Cerita Matematika Materi Sistem

Cartesius: Jurnal Pendidikan Matematika Vol. 3, No. 1

CProdi Pendidikan Matematika Universitas Katolik Santo Thomas 
Persamaan Linier Dua Variabel Berdasarkan Analisis Newman. Jurnal Online.

[18] Susanto,A.2013. Teori Belajar dan Pembelajaran di Sekolah Dasar. Bandung: Alfabeta.

[19] Susiowati \& Ratu. 2018. Analisis Kesalahan Siswa Berdasarkan Tahapan Newman dan Scaffolding Pada Materi Aritmatika Sosial. Jurnal Pendidikan Matematika. VII(1).

[20] White, A. L. 2010. Numeracy, Literacy, and Newman's Error Analysis Journal of Science and Mathematics Education in Southeast Asia. 33(2). p.129-148.

[21] Wiyanto, et al. 2011. Panduan Penulisan Skripsi dan Artikel Ilmiah. Semarang: Fakultas Matematika dan Ilmu Pengetahuan Alam Universitas Negeri Semarang. 